\title{
Intraplate Transtensional Tectonics in the East Antarctic Craton: Insight from Buried Subglacial Bedrock in the Lake Vostok-Dome C Region
}

\author{
Paola Cianfarra, Francesco Salvini \\ Science Department, Università degli Studi Roma Tre, Roma, Italy \\ Email: paola.cianfarra@uniroma3.it, francesco.salvini@uniroma3.it
}

Received July 13, 2013; revised August 17, 2013; accepted September 12, 2013

Copyright (C) 2013 Paola Cianfarra, Francesco Salvini. This is an open access article distributed under the Creative Commons Attribution License, which permits unrestricted use, distribution, and reproduction in any medium, provided the original work is properly cited.

\begin{abstract}
This study presents the results of forward numerical models of a series of sections of the Aurora Trench (East Antarctica) derived from radio echo-sounding data that allowed reconstructing the 3D shape of the Aurora Fault, a crustal listric normal fault characterized by a length exceeding $100 \mathrm{~km}$. A similar extensional fault setting allows replicating the asymmetric buried morphology of the magnetic basement at the Lake Vostok depression derived by the available gravity and magnetic profiles. Both the Aurora and Vostok listric fault reach their basal decollment at $34 \mathrm{~km}$ depth, possibly the base of the crust in this intracratonic environment. Integration of these results with the existing geologic interpretations of the tectonic origin of the Concordia Trench by normal faulting allowed framing the Concordia, Aurora and Vostok normal faults within an intraplate transtensional corridor with a left-lateral movement component. The westward projection of the proposed strike-slip deformation belt may develop in correspondence of an older tectonic lineament stretching from the Eastern flanks of the Gamburtsev Subglacial Mts to the Lambert rift and characterized by a poly-phased complex tectonic history. The possible Cenozoic reactivation of these structures is discussed in the paper.
\end{abstract}

Keywords: Intracratonic Tectonics; Numerical Modelling; East Antarctica

\section{Introduction}

The Antarctic plate has a unique geodynamic setting since it is almost completely surrounded by divergent or conservative margins, with the limited exception of the subduction zones of South Sandwich and South Shetland Islands [1,2]. East Antarctica is a Precambrian craton that played a central role in early supercontinents such as Rodinia and Gondwana in Precambrian and Paleozoic times [3]. A large interval of the late Mesozoic and Cenozoic geological history of Antarctica is dominated by the break-up of Gondwana; its separation forms the Australia plate, and its movement towards the present polar location through a polifased evolution includes continental rifting, block translations, uplift of the Transantarctic Mountains and widespread magmatism [4-11].

Due to climatic and logistic difficulties, at present several unanswered questions concerning the geological setting of the innermost part of Antarctica still exist. The East Antarctic Ice Sheet (EAIS) prevents the direct analysis of the subglacial geology and landscape, leaving most of the geologic information derived from geophysical investigations. Only sparse outcrops along the perimeter of the continent complement the limited geological information about the inner parts of the craton. Nevertheless there is increasing interest in the understanding of the geodynamic setting of the Antarctic plate, currently being investigated by a variety of new geophysical, structural, geomorphic and remote sensing studies. It is widely acknowledged that the subglacial geological setting controls the ice sheet dynamics that in turn influence polar climate changes during Cenozoic times as the Drake Passage opening and the drifting from Australia [12-16]. The feedback mechanisms between climate, buried landscape and geodynamic processes challenge the developments of new original approaches to unravel the Cenozoic tectonic evolution of the East Antarctic Craton (EAC). In this way the Scientific Committee for Antarctic Research promotes interdisciplinary research projects (ACE, SALE, ACGS, AGAP Projects). 
The aim of this paper is to provide new clues on the tectonic setting of central part of the EAC between the Vostok and the Belgica Subglacial Highlands (between Longitude $100^{\circ} \mathrm{E}$ and $130^{\circ} \mathrm{E}$ ) based on the existing geologic interpretation of the available geophysical data, including Radio Echo Sounding profiles [17-20] and their integration with the tectonic modeling of the Aurora Trench and a new tectonic interpretation of the magnetic and gravity anomaly profile at the Lake Vostok based on tectonic modeling.

\section{Main Physiographic Features, Proposed Origin and Dry Bedrock-Ice Sheet Contact}

The investigated area is located in the central part of the EAC where a cluster of about 50 subglacial lakes exists including the largest ones, namely Vostok, Concordia, Aurora and Vincennes Lakes [21] and is comprised between Longitude $100^{\circ} \mathrm{E}$ and $130^{\circ} \mathrm{E}$. Our knowledge of the bedrock physiography derives from RES data collected during the Italian Antarctic expedition from 1995 to 2003 [22-25]. The bedrock in this region is characterized by the presence of three, nearly parallel main depressions with a length exceeding $150 \mathrm{~km}$ and tens of kilometer wide
(Figure 1). From E to $\mathrm{W}$ the articulated bedrock physiography includes the Concordia Trench, the Aurora Trench and the Vostok Subglacial depression. Further E another elongated depression exists, the Adventure Subglacial Trench.

The RES profiles and their derived bed map showed that the Aurora and Concordia trough have a typical half graben shape (Figures 2(a) and (b)), characterized by steep across strike profiles that contrast with the smoother along strike profiles. A saddle characterizes the central part of these depressions giving them two opposed slope directions (Figure 1). The two valley shoulders show small differences in elevation although a strong slope dip asymmetry can be observed: the eastern side has a steep slope, while the western one has a flatter, variable dip slope that produces a smoothly rounded profile. These morphologies strongly resemble the shape of fault controlled valleys, and specifically depressions resulting from the activity of listric, normal faults (e.g. East African rift valleys) [26].

[19] evidentiated the role played by tectonics in its morphological evolution by interpreting the available RES profiles of the bedrock in the Vostok-Dome $\mathrm{C}$ region and providing a key to interpret the geological

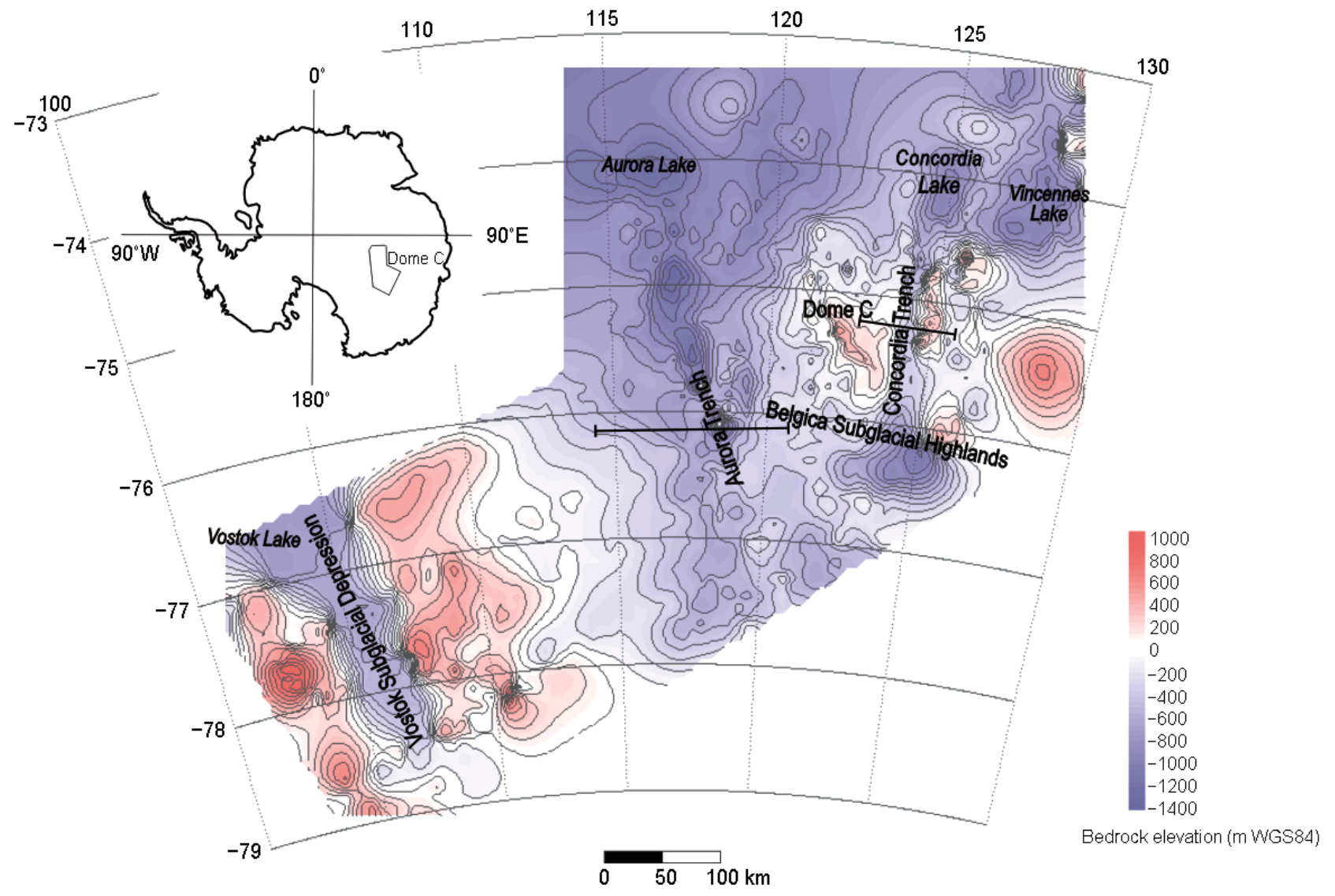

Figure 1. Location of the investigated area within the EAC and the main physiographic units. Black lines represent the trace of the RES profiles in Figures 2(a) and (b). 
origin of the subglacial lakes of the region. Among the three main types (e.g. compressional, extensional and transcurrent tectonic style of deformation), the authors [19] proposed a tectonic origin from the presence of normal listric faults for the elongated depressions. [20] proved the tectonic origin of the Concordia Trough by modeling the 3D surface of the normal listric fault associated to its development by integrating a series of numerical models along RES profiles that cross cut that depression.

The saddle in the Aurora and Concordia Trenches testifies for the origin of these depressions as developed along a pre-existing morpho-tectonic lineament (Figure 1). This is a characteristic feature of tectonically controlled landscapes as observed at the various scales on the Earth landscape, from the Rodan-Rhein graben [27] in Europe to the Val Roveto in the Appennines, a longer than $70 \mathrm{~km}$ elongated valley with opposed drainage developed along a major fault [28]. The across strike asymmetry is a typical feature of many fault-related valleys, as that occupied by the Lake Baikal [29] developed within an intracratonic strike slip deformation belt [30]. Eventually, the symmetry in the elevation of the opposite shoulders is in favor of an extensional or transtensional tectonic environment. The morphological high observed in correspondence of the Eastern side of the valleys may well derive from the isostatic/elastic flexure rebound resulting from the variation in the crustal thickness produced by tectonic displacements as in extensional faulting [27].

The absence of flat zones in the valley floor of the Aurora and Concordia Trenches testifies for the absence of an alluvial sedimentary episode as the last morphological event, apart from the lakes. The asymmetrical trench landscape has not been obliterated by later erosional episodes including periods of wet ice-bedrock contact of the ice cap. This implies that the reasonable formation age for these valleys spans from immediately prior to the ice cap formation at about $38 \mathrm{Ma}$ [14], as tectonically related fluvial valleys, to recent times beneath the dry bedrock-ice cap contact. An older age may be reasonably considered unreliable since the asymmetry would have been obliterated very fast by continental erosional processes (i.e. peneplanation). Again, the presence of a bedrock with different erosional strength not even produced by tectonic contacts could hardly produce the same characteristic steeper slope for the three trenches (i.e. the steeper slopes are the eastern ones in Concordia, Aurora and Vostok, see Figure 2). In the light of the above considerations it is reasonable to assume that since the onset of the EAIS with its predominant dry ice-rock contact, the tectonic activity should represent the major, yet negligible, modelling agent of the subglacial landscape.

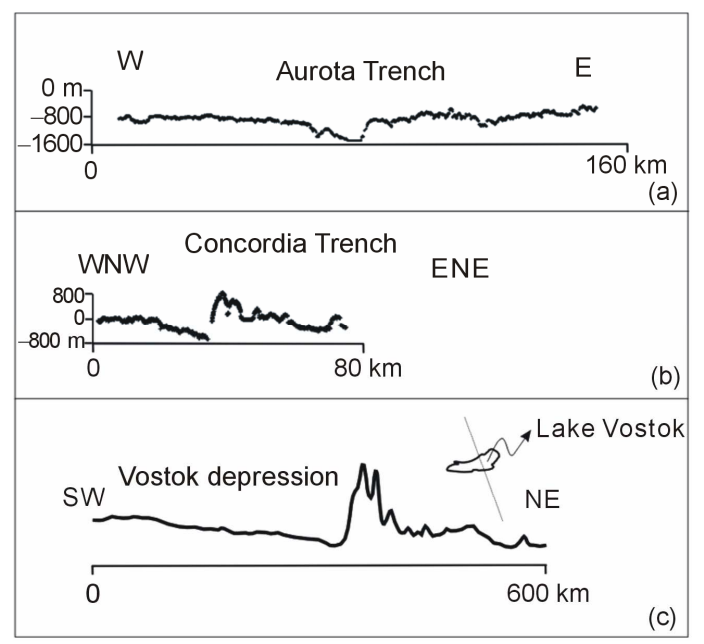

Figure 2. RES profiles of the Aurora Trench (a) and Concordia Trench (b). Computed morphology of the top of the magnetic basement, redrawn after [18] and its location (c).

Characteristic topographic signature develops in area affected by tectonic processes.

In this work we used the unique imprint of the extensional tectonic on the landscape to prove the tectonic origin of the Aurora Trench by modeling the present day morphology as the result of the relative movement between the footwall and the hangingwall of a regional fault with normal component. This fault produces the observed asymmetry in its topographic expression. The used methodology is the same used by $[19,20]$.

The length of the Aurora Trench let to estimate an over $100 \mathrm{~km}$ horizontal length for this fault. This implies a vertical dimension of the order of the tens of $\mathrm{km}$ and gives to this fault a crustal importance. The same was proposed by [20] for the Concordia normal fault.

These landscapes were replicated by a series of numerical Hybrid Cellular Automata (HCA) models, using the FORCtre software developed to model the evolution of complex geological structures [31,32]. The comparison and tuning of these models with the bedrock morphology allowed to constrain the tectonic styles responsible for the formation of subglacial depressions.

In the western side of the investigated area, Lake Vostok occupies a wedge shaped, elongated depression roughly NNW-SSE oriented $[17,23,33]$. The lake is clearly visible on synthetic scale satellite images (Radarsat and MODIS mosaic) of Antarctica and is characterized by a longer axis being about $260 \mathrm{~km}$ long and a width that does not exceed $80 \mathrm{~km}$. These features resemble the morphology of fault controlled lakes like the Lake Malawi and Lake Baikal. Aeromagnetic interpretation from [18] shows that the Vostok depression is characterized by an asymmetry of the magnetic basement that reasonably coincides with the subglacial topography (Figure 2(c)). Again, as in the Aurora and Concordia trenches [19], the 
eastern Vostok slope is steeper than the smoothly rounded western slope. [18] identifies a tectonic boundary beneath the Vostok Subglacial depression. According to the Authors' interpretation of gravity and magnetic data, this boundary could be the result of a thrust sheet emplacement onto an older passive continental margin of Proterozoic age. [34] frame the Lake Vostok depression within an intracratonic rift belt stretching inland from the Pryzd Bay, and the eastern foot of Gamburtsev Mountains. The proposed age for the associated tectonic event is Paleozoic. In this paper we also present the result of a numerical model by HCA technique that allowed to replicate the asymmetric morphology of the magnetic basement beneath the Lake Vostok as the result of extensional tectonic.

\section{Numerical Modeling of the Aurora Fault}

With a similar approach of [20], we present the results of the 3D modeling of the morphology of the Aurora Trench as derived by the presence and activity of a listric normal fault by means of forward numerical modeling of a series of across geological sections to replicate the development of the buried bedrock morphology as derived from radio echo-sounding (RES) data in the Aurora Trough area. The modeling was performed by HCA (Hybrid Cellular Automata) technique implemented in the FORCtre software [31,32]. This technique is a hybrid methodology that combines the cellular automata and the finite element method principles. The crust in the investigated area is replicated through a large amount of cells characterized by simple, first-order geometrical and/or physical relational laws.

The forward modeling consisted in simulating the development of the present day bedrock morphology by the hangingwall sliding along a fault with a given geometry and displacement along a series of transversally re-projected RES profiles across the trenches. This operation was necessary to successfully model the evolution of the morphology by confirming the evolution as a cylindrical deformation (i.e. not significant lateral change in the fault geometry in the neighborhood of each section). A similar fault setting was applied to the prepared sections slightly tuning fault geometry and displacement until the misfit between bedrock morphology deduced from RES data and the model was minimized. Careful tuning of fault geometry included the comparison of each modeled section with the adjacent ones, in order to better constrain the along strike fault geometry and displacement. Results from this comparison were then used to improve the fit of the adjacent sections in a feedback, forwardmodeling, process.

The 3D geometry of the Aurora Fault was achieved by re-projecting the modeled section along its original strike and eventually the 2D georeferenced fault traces were gridded by a properly oriented asymmetric interpolator. Minor topographic features, with length up to $5 \mathrm{~km}$ were considered as the effects of secondary geological/climatological features and were ignored in the fit. The reliability and criticity of the final result for each profile was successfully tested within a vertical and horizontal resolution of about $170 \mathrm{~m}$ for an average section length of about $100 \mathrm{~km}$.

The Aurora fault surface was modeled along 6 georeferenced RES profiles trending between ENE-WSW and E-W. The location and initial dip of the fault trace was inferred from the position of the fault-scarp in the bedrock morphology, representing the eastern steeper trench side. The same fault trace was used to simulate the bedrock morphology for the six modeled sections, the only difference being in the computed displacements. The modeled fault traces were gridded by an asymmetric NNW-SSE trending interpolator, using the kriging method [35]. The obtained 3D fault grid is characterized by a rectangular grid spacing of $1843 \mathrm{~m}$ in the Easting direction (x-axis) and $1854 \mathrm{~m}$ in the Northing direction (y-axis).

The resulting Aurora Fault is NNW-SSE oriented, dips to the WNW, and shows a regular listric shape that fades into a detachment surface at a depth of about $34 \mathrm{~km}$ (Figure 3(a)). The vertical displacement is limited to a maximum of about $700 \mathrm{~m}$ in its central-southern sector and minimum computed values of less than $400 \mathrm{~m}$ at both edges.

Its initial dip near the surface is $63^{\circ}$ till the depth of $17 \mathrm{~km}$ then it gently rotates to $45^{\circ}$ in the following $6 \mathrm{~km}$. From the depth of $23 \mathrm{~km}$ it progressively flattens and reaches its basal detachment at the base of the crust (34 $\mathrm{km})$. The found ratio between fault length and maximum observed displacement is about $1 / 140$. This value is about half of the general expected values of about $1 / 70$ for faults in the upper crust [36]. This discrepancy may either relate to the presence of an unknown yet significant horizontal component not evidenced in the modeling, to the splitting of the modeled Aurora Fault into an array of smaller normal faults, or eventually to an older history of the fault; if this is the case, the computed vertical displacements record only its later history, after the ice cap took place and the erosional processes arrested.

\section{Proposed Cenozoic Tectonic Framework for the Vostok-Dome C Region}

The modeled Aurora Fault (Figure 3(a)) is in agreement with the tectonic style of the Concordia Fault [20]. The Concordia Fault is N-S oriented, dips to the West and has a length of at least $180 \mathrm{~km}$ (Figure 3(b)). The resulting surface is less regular than the Aurora Fault one. The listric geometry is less accentuated and this may be responsible for the regional small tilt of the bedrock 


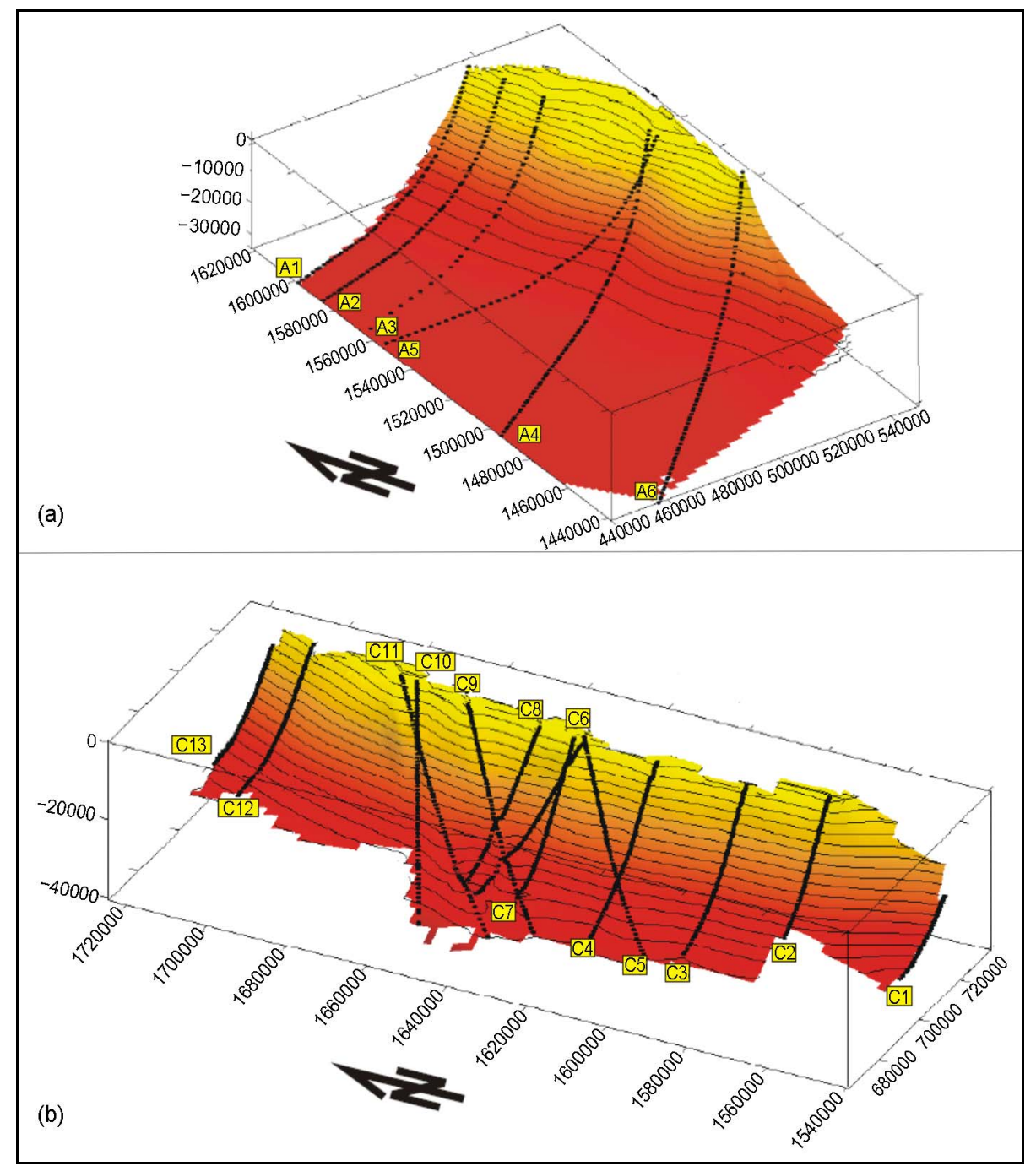

Figure 3. 3D geometry of the Aurora (a) and Concordia Fault (b).

surface across the Concordia Trench. In its northern sector the proposed model of the fault shows a change in strike that testifies its possible splitting into two different fault segments. The boundary between the two segments corresponds to the saddle in the mid portion of the Concordia Trench (Figure 1). The modeled displacement goes regularly from about $0 \mathrm{~m}$ in the northern termination to its maximum of about $1150 \mathrm{~m}$ in its southern tip. This indicates that either this fault extends southward, where no RES profile are available, or that it is truncated by the presence of transverse fault(s) at its termination.

Results confirm the tectonic origin of the Aurora Trench with a framework similar to the Concordia one [20]. Both these subglacial troughs relate to the activity of two, near-parallel listric normal faults with a length of over $100 \mathrm{~km}$ and a vertical dimension of the order of the tens of $\mathrm{km}$. The modeled depth of the basal detachment of the Aurora Fault is about $34 \mathrm{~km}$, possibly corresponding to the base of the crust. At the same depth $[17,18]$ on the basis of gravity data modeling, placed in the Vostok area a density contrast corresponding to the crust-mantle boundary.

The same tectonic model may well fit also in the Lake Vostok origin. The asymmetrical morphology of the top of the magnetic basement in the Vostok depression (Figure 2(c)) presented by [18] as well as the wedge shaped morphology of the basin [33], with again a marked slope asymmetry, open the possibility of a similar tectonic environment (i.e. listric normal fault) responsible for the origin of this depression.

A regional HCA model was prepared to replicate the asymmetrical geometry of the top of the magnetic basement in the Vostok depression as proposed by [18] as well as the vertical and lateral distribution of crustal densities proposed by [18]. The prepared 2D HCA model is characterized by a length exceeding $350 \mathrm{~km}$ and investigates a crustal thickness of over $45 \mathrm{~km}$ (Figure 4). The proposed crustal densities distribution and the wedge 

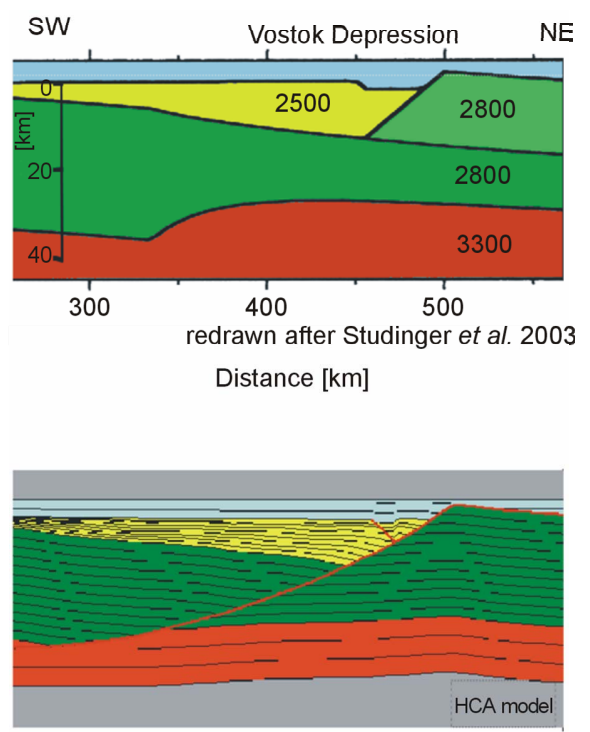

Figure 4. Tectonic model from gravity modelling of the Lake Vostok after [18] (upper part) and HCA model showing that the Vostok depression and the predicted crustal density distribution may easily result from the activity of a crustal, listric normal fault.

shape geometry of the Vostok basin [18,33] (upper part of Figure 4) are well replicated through the activity of a listric normal fault that reaches its basal decollment at the depth of $34 \mathrm{~km}$ with a displacement of over $20 \mathrm{~km}$. The unloading due to the activity of this regional, crustal listric fault is responsible for the elastic flexure rebound observed in the footwall of the fault (north-eastern margin of the Vostok depression).

Also [37] proposed to frame the lake Vostok, the Aurora and Concordia Trench within the same tectonic environment based on the lineament domain analysis of the ice cap surface.

Results from the modeling of the Aurora Trench and of the crustal densities at the Lake Vostok depression, and the proposed tectonic setting of the Concordia Trench well frame with the presence of a set of crustal sized, listric normal faults. This NW-SE to N-S faults frame within a roughly SW-NE corridor within the inner part of the EAC that extends at least from the Lake Vostok to the Aurora and Concordia trenches with an average width of about $200 \mathrm{~km}$ and a length of over 800 $\mathrm{km}$. This corridor is characterized by an array of roughly $\mathrm{N}-\mathrm{S}$ trending normal faults in en-echelon configuration with a limited right step component. This allows to speculate on the tectonic regime of the Vostok-Dome C region, possibly in Cenozoic times. The Aurora and Concordia faults, as well as a similar fault beneath the Lake Vostok, may well represent the effect of a transtensional corridor produced by a nearly E-W left-lateral shear zone or by its fading to the East in a horse-tail array of transtensional to extensional faults (Figure 5).
This scenario describes the presence of a transtensional intraplate shear zone within the EAC. In this scenario the kinematics of this intraplate shear zone could relate to a crustal left-lateral relative motion within the EAC. This kinematics induces an extensional stress within the corridor responsible for the Concordia, Aurora and Vostok normal faults. A similar tectonic style has been recognised in the Victoria Land-Ross Sea region, in the easternmost part of the East-Antarctica Craton [5,38]. Similar scenarios have already been found in other cratonic regions as for the Baikal Lake tectonic evolution [29].

The proposed E-W intraplate strike-slip deformation belt with a left-lateral movement is compatible with the kinematics related to the rifting in the Southern Ocean between Australia and Antarctica (SE Indian Ridge) and may well derive from the kinematic reaction to the interaction of this drifting with the plate motion constraints of the Antarctica plate all around (Figure 6).

The westward projection of the proposed transtensional corridor towards the eastern flanks of the Gamburtsev Subglacial Mts may well develop in correspondence of an older tectonic lineament that was active during the Proterozoic assembly of the East Antarctica, later rejuvenated during Permian and Cretaceous as a rifting system stretching through the Pridz Bay [12]. Other subglacial depressions of tectonic origin [41] are located within the proposed deformation belt. Some of them host subglacial lakes including the $90^{\circ} \mathrm{E}$ and Sovetskaya Lakes. Furthermore, at the eastward projection of the deformation belt the Adventure Subglacial Trench is characterized by a sharp asymmetric across-strike morphological profile suggesting again an extensional tectonic origin [42]. Aeromagnetic and gravity investigations in the Concordia Trench [43] both confirm the

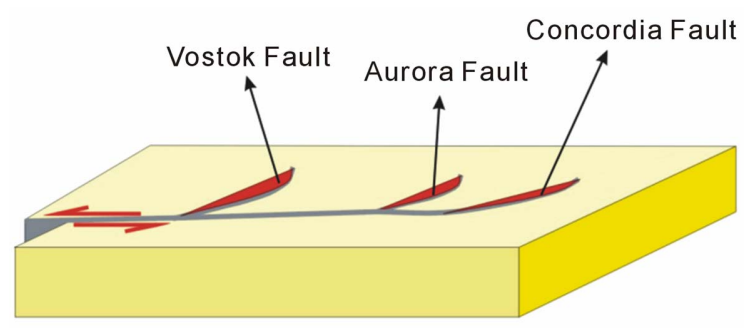

(a)

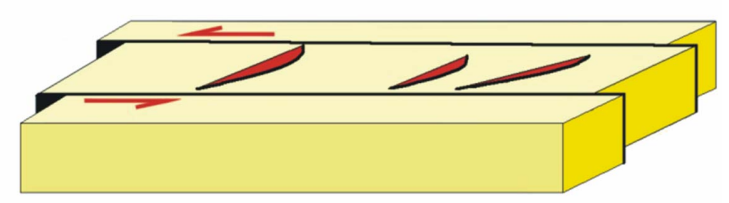

(b)

Figure 5. Proposed tectonic model of the Vostok-Dome C area. (a) Horse tail array of transtensional faults; (b) Intraplate strike slip deformation belt. 


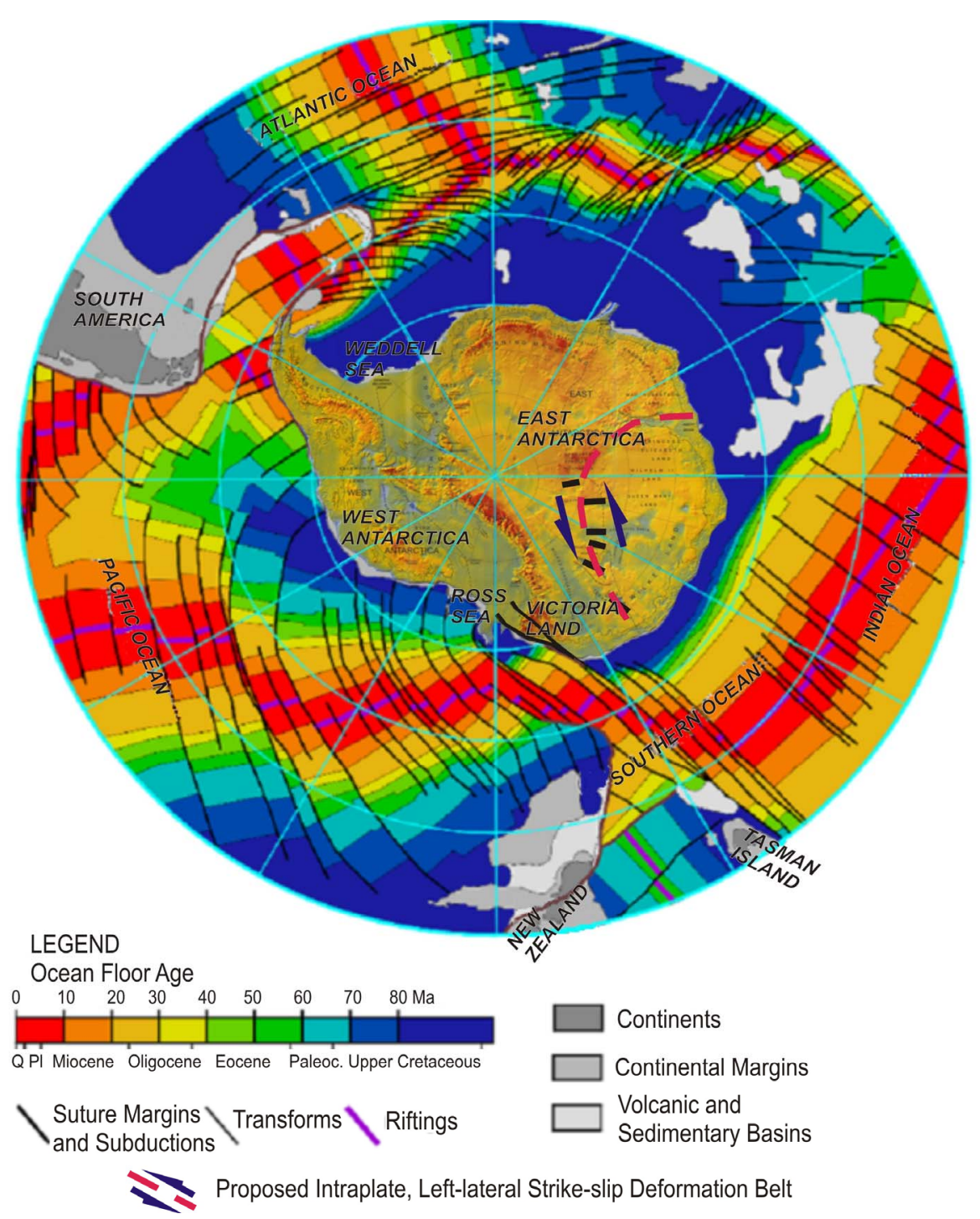

Figure 6. Proposed intraplate strike slip deformation belt within the East Antarctic Craton. Combined and modified from $[39,40]$.

presence of a crustal thickness asymmetry at the depression marked by a steeper contrast to the E side. This geometry is fully compatible with the proposed tectonic model.

Although an internal significant deformation of the EAC at the plate tectonic scale is expected due to the poor compatibility of its relative motions at its plate boundaries, further studies are required to fully constrains the areal dimension of this transtensional intraplate corridor and specifically how to frame it with the nearby regional tectonic features as the Prydz Bay, the Wilkes basin, and the Gamburtsev Mountains.

The observed set of depressions within the EAC are not unique. Similar depression features with poor age constrains are present also in the internal regions of other cratons. The presented model might help in better constrains their origin and provide new (younger?) time con- strains for their development, toward a better knowledge of the internal deformations of cratonic areas as produced by plate interactions.

\section{Conclusions}

Results from the forward numerical modelling of RES data in the Vostok and Dome $C$ region address a series of issue about the geologic setting of the inner part of the EAC.

The origin of the Aurora Trench relates to the activity of crustal, listric faults with normal component. The modelling allowed reconstructing the 3D geometry of this regional tectonic lineament of the ice-buried bedrock. In this way the HCA technique proved a useful tool to replicate the influence of fault activity on the topography and therefore to investigate the structural setting of re- 
gions where the main modelling agent is the tectonic activity. This technique may well be applied to planetary studies, where we observe a limited evolution of the topography with time.

Based on HCA modeling of the asymmetric morphology of the magnetic basement at the Lake Vostok depression we propose for this wedge-shaped basin a tectonic environment similar to the Aurora and Concordia Trench, namely a crustal normal fault with the same listric geometry as the Aurora Fault. Following the proposed tectonic model, it is possible to speculate on the regional tectonic setting of the Vostok-Dome $\mathrm{C}$ region. Aurora, Concordia and Vostok faults might represent the effect of a transtensional corridor related to a left-lateral, strike-slip deformation belt within the central part of the EAC possibly rejuvenating in Cenozoic times an older tectonic lineament.

\section{Acknowledgements}

Research was carried out in the joint framework of the Project on Glaciology of the PNRA-MIUR, and was financially supported by the PNRA Consortium through collaboration with ENEA Roma. This work is an Italian contribution to Concordia Station projects and to the EPICA, a joint ESF/EU (European Science Foundation) scientific programme funded by the European Commission and by national contributions from Belgium, Denmark, France, Germany, Italy, the Netherlands, Norway, Sweden, Switzerland and the United Kingdom. We thank for the anonymous reviewers.

\section{REFERENCES}

[1] D. E. Hayes, "Tectonics and Age of the Oceanic Crust: Circum-Antarctic to $30^{\circ} \mathrm{S}$," In: D. E. Hayes, Ed., Marine Geological and Geophysical Atlas of the Circum-Antarctic to $30^{\circ} \mathrm{S}$., American Geophysical Union, Washington DC, 1991, pp. 47-56.

http://dx.doi.org/10.1029/AR054p0047

[2] L. A. Lawver and L. M. Gahagan, "Evolution of Cenozoic Seaways in the Circum-Antarctic Region,” Palaeogeography, Palaeoclimatology, Palaeoecology, Vol. 198, No. 1, 2003, pp. 11-37.

http://dx.doi.org/10.1016/S0031-0182(03)00392-4

[3] T. H. Torsvik, “The Rodinia Jigsaw Puzzle," Science, Vol. 300, No. 5624, 2003, pp. 1379-1381. http://dx.doi.org/10.1126/science.1083469

[4] T. A Stern and U. S. ten Brink, "Flexural Uplift of the Transantarctic Mountains,” Journal of Geophysical Research, Vol. 94, No. B8, 1989, pp. 10315-10330. http://dx.doi.org/10.1029/JB094iB08p10315

[5] F. Salvini, G. Brancolini, M. Busetti, F. Storti, F. Mazzarini and F. Coren, "Cenozoic Geodynamics of the Ross Sea Region, Antartica: Crustal Extension, Intraplate Strike-Slip Faulting Tectonic Inheritance,” Journal of Geo- physical Research, Vol. 102, No. B11, 1997, pp. 2466924696. http://dx.doi.org/10.1029/97JB01643

[6] S. Tonarini, S. Rocchi, P. Armienti and F. Innocenti, "Constraints on Timing of Sea Rifting Inferred from Cenozoic Intrusions from the Northern Victoria Land, Antarctica,” In: C. A. Ricci, Ed., The Antarctic Region: Geological Evolution Processes. Proceedings of the 7th International Symposium on Antarctic Earth Sciences, Terra Antarctica, Siena, 1997.

[7] S. C. Cande, J. M. Stock, R. D. Muller and T. Ishihara, "Cenozoic Motion between East and West Antarctica," Nature, Vol. 404, No. 6774, 2000, pp. 145-150. http://dx.doi.org/10.1038/35004501

[8] F. Ferraccioli, F. Coren, E. Bozzo, C. Zanolla, S. Gandolfi, I. E. Tabacco and M. Frezzotti, "Rifted Crust at the East Antarctic Craton Margin; Gravity and Magnetic Interpretation along a Traverse across the Wilkes Subglacial Basin Region,” Earth and Planetary Science Letters, Vol. 192, No. 3, 2001, pp. 407-421. http://dx.doi.org/10.1016/S0012-821X(01)00459-9

[9] P. Fitzgerald, "Tectonics and Landscape Evolution of the Antarctic Plate Since the Break up of Gondwana, with an Emphasis on the West Antarctic Rift System and the Transantarctic Mountains,” In: J. A. Gamble, D. N. B. Skinner and S. Henry, Eds., Antarctica at the Close of a Millennium, Royal Society of New Zealand Bulletin, Wellington, Vol. 35, 2002, pp. 453-469.

[10] F. Rossetti, F. Lisker, F. Storti and L. A. Laufer, "Tectonic Denudation History of the Rennick Graben (North Victoria Land): Implication for the Evolution of Rifting between East and West Antarctica,” Tectonics, Vol. 22 No. 2, 2003, p. 1016.

http://dx.doi.org/10.1029/2002TC001416

[11] T. A. Jordan, F. Ferraccioli, E. Armadillo and E. Bozzo, "Crustal Architecture of the Wilkes Subglacial Basin in East Antarctica, as Revealed from Airborne Gravity Data,” Tectonophysics, Vol. 585, 2012, pp. 196-206. http://dx.doi.org/10.1016/j.tecto.2012.06.041

[12] F. Ferraccioli, C. A. Finn, T. A. Jordan, R. E. Bell, L. M. Anderson and D. Damaske, "East Antarctic Rifting Triggers Uplift of the Gamburtsev Mountains,” Nature, Vol. 479, No. 7373, 2011, pp. 388-394. http://dx.doi.org/10.1038/nature10566

[13] S. Bo, M. J. Siegert, S. M. Mudd, D. Sugden, S. Fujita, C. Xiangbin, J. Yunyun, T. Xueyuan and L. Yuansheng, "The Gamburtsev Mountains and the Origin and Early Evolution of the Antarctic Ice Sheet,” Nature, Vol. 459, No. 7248, 2009, pp. 690-693. http://dx.doi.org/10.1038/nature08024

[14] R. M. DeConto and D. Pollard, "Rapid Cenozoic Glaciation of Antarctica Induced by Declining Atmospheric $\mathrm{CO}_{2}$," Nature, Vol. 421, No. 6920, 2003, pp. 245-249. http://dx.doi.org/10.1038/nature01290

[15] J. P. Kennet, "Cenozoic Evolution of Antarctic Glaciation, the Circum-Antarctic Oceans and Their Impact on Global Paleoceanography," Journal of Geophysical Research, Vol. 82, No. 27, 1977, pp. 3843-3859. http://dx.doi.org/10.1029/JC082i027p03843

[16] M. J. Siegert, J. Taylor and A. J. Payne, "Spectral Rough- 
ness of Subglacial Topography and Implication for Former Ice-Sheet Dynamics in East Antarctica," Global and Planetary Change, Vol. 45, No. 1, 2005, pp. 249-263. http://dx.doi.org/10.1016/j.gloplacha.2004.09.008

[17] M. Studinger, R. E. Bell, G. D. Karner, A. A. Tikku, J. W. Holt, D. L. Morse, T. G. Richter, S. D. Kempf, M. Peters, D. D. Blankenship, R. E. Sweeney and V. Rystrom, "Ice Cover, Landscape Setting, and Geological Framework of Lake Vostok, East Antarctica," Earth and Planetary Science Letters, Vol. 205, No. 3-4, 2003, pp. 195-210. http://dx.doi.org/10.1016/S0012-821X(02)01041-5

[18] M. Studinger, G. D. Karner, R. E. Bell, V. Levin, C. A. Raymond and A. A. Tikku, "Geophysical Models for the Tectonic Framework of the Lake Vostok Region, East Antarctica," Earth and Planetary Science Letters, Vol. 216, No. 4, 2003, pp. 663-677. http://dx.doi.org/10.1016/S0012-821X(03)00548-X

[19] I. E. Tabacco, P. Cianfarra, A. Forieri, F. Salvini and A. Zirizotti, "Physiography and Tectonic Setting of the Subglacial Lake District between Vostok and Belgica Subglacial Highlands (Antarctica),” Geophysical Journal International, Vol. 165, No. 3, 2006, pp. 1029-1040. http://dx.doi.org/10.1111/j.1365-246X.2006.02954.x

[20] P. Cianfarra, A. Forieri, F. Salvini, I. E. Tabacco and A. Zirizotti, "Geological Setting of the Concordia TrenchLake System in East Antarctica,” Geophysical Journal International, Vol. 177, No. 3, 2009, pp. 1305-1314. http://dx.doi.org/10.1111/j.1365-246X.2009.04123.x

[21] M. J. Siegert, S. Carter, I. E. Tabacco, S. Popov and D. D. Blankenship, "A Revised Inventory of Antarctic Subglacial Lakes,” Antarctic Science, Vol. 17, No. 3, 2005, pp. 453-460. http://dx.doi.org/10.1017/S0954102005002889

[22] I. E. Tabacco, A. Passerini, F. Corbelli and M. Gorman, "Determination of the Surface and Bed Topography at Dome C, East Antarctica,” Journal of Glaciology, Vol. 44, No. 146, 1998, pp. 185-191.

[23] I. E. Tabacco, C. Bianchi, A. Zirizzotti, A. Zuccheretti, A. Forieri and A. Della Vedova, "Airborne Radar Survey above Vostok Region, East Central Antarctica: Ice Thickness Lake Vostok Geometry,” Journal of Glaciology, Vol. 48, No. 160, 2002, pp. 62-69. http://dx.doi.org/10.3189/172756502781831656

[24] A. Forieri, L. Zuccoli, A. Bini, A. Zirizzotti and I. E. Tabacco, "New Bed Topography of Dome C," Annals of Glaciology, Vol. 39, No. 1, 2004, pp. 321-325. http://dx.doi.org/10.3189/172756404781814456

[25] A. Forieri, I. E. Tabacco, L. Cafarella, S. Urbini, C. Bianchi and A. Zirizotti, "Evidence for Possible New Subglacial Lake along a Radar Transect crossing the Belgica Highlands and the Concordia Trench," Terra Antarctica Report, Vol. 14, No. 1, 2008, pp. 209-212.

[26] D. W Burbank and R. S. Anderson, “Tectonic Geomorphology,” Blackwell Sciences Ltd, Oxford, 2001.

[27] J. K. Weissel and G. D. Karner, "Flexural Uplift of Rift Flanks Due to Mechanical Unloading of the Lithosphere during Extension,” Journal of Geophysical Research, Vol. 94, No. B10, 1989, pp. 13919-13950. http://dx.doi.org/10.1029/JB094iB10p13919

[28] P. Montone and F. Salvini, "Evidences of Strike-Slip
Tectonics in the Apenninic Chain near Tagliacozzo (L'Aquila), Abruzzi, Central Italy,” Bollettino della Societa Geologica Italiana, Vol. 110, 1991, pp. 617-619.

[29] U. S. ten Brink and M. H. Tayor, "Crustal Structure of Central Lake Baikal: Insight into Intracontinental Rifting,” Journal Geophysical Research, Vol. 107, No. B7, 2002, pp. 2-15.

[30] F. Storti, R. E. Holdsworth and F. Salvini, "Intraplate Strike-Slip Deformation Belts,” Geological Society, London, Special Publications, Vol. 210, 2003, pp. 1-14. http://dx.doi.org/10.1144/GSL.SP.2003.210.01.01

[31] F. Salvini, F. Storti and K. McClay, "Self Determining Numerical Modelling of Compressional Fault Bend Folding,” Geology, Vol. 29, No. 9, 2001, pp. 839-842. http://dx.doi.org/10.1130/0091-7613(2001)029<0839:SD NMOC $>2.0 . \mathrm{CO} ; 2$

[32] F. Salvini and F. Storti, “Active-Hinge-Folding-Related Deformation and Its Role in Hydrocarbon Exploration and Development-Insight from HCA Modelling,” In: K. R. McClay, Ed., Thrust Tectonics and Hydrocarbon Systems: A.A.P.G. Memoirs 82, American Association of Petroleum Geologist, Tulsa, 2004, pp. 453-472.

[33] I. Y. Filina, D. D. Blankenship, M. Thoma, V. V. Lukin, V. N. Masolov and M. K. Sen, "New 3D Bathymetry and Sediment Distribution in Lake Vostok: Implication for Pre-Glacial Origin and Numerical Modeling Processes within the Lake," Earth and Planetary Science Letters, Vol. 276, No. 1, 2008, pp. 106-114. http://dx.doi.org/10.1016/j.epsl.2008.09.012

[34] G. L. Leitchenkov, V. N. Masolov, V. V. Lukin, S. A. Bulat, R. G. Kurinin and V. Lipenkov, "Geological Nature of Suglacial Lake Vostok," Geophysical Research Abstract, Vol. 5, No. 1, 2003, Article ID: 00433.

[35] N. A. Cressie, “The Origins of Kriging," Mathematical Geology, Vol. 22, No. 3, 1991, pp. 239-252. http://dx.doi.org/10.1007/BF00889887

[36] J. J. Walsh and J. Watterson, "Analysis of the Relationship between Displacements and Dimensions if Faults," Journal of Structural Geology, Vol. 10, No. 3, 1998, pp. 239-247.

[37] P. Cianfarra and F. Salvini, "Ice Cap Surface Lineaments in the Vostok-Dome C Area, East Antarctica. What Are They Telling Us on the East Antarctica Craton Tectonics?” Terra Antarctica Reports, Vol. 14, No. 1, 2008, pp. 203-208.

[38] G. Capponi, L. Crispini and M. Meccheri, "Structural History and Tectonic Evolution of the Boundary between the Wilson and Bowers Terranes, Lanterman Range, Northern Victoria Land, Antarctica,” Tectonophysics, Vol. 312, No. 2, 1999, pp. 249-266.

[39] C. A. Ricci, C. Baroni, G. Brancolini, R. Palmeri, F. Salvini and F. Talarico, "La Storia Geologica. Lineamenti Geologici dell'Antartide,” In: C. Baroni, Ed., Antartide Terra di Scienza e Riserva Naturale, Terra Antarctica Publication, Siena, 2001, pp. 88-112.

[40] M. B. Lythe, D. G. Vaughan and the BEDMAP Consortium, "BEDMAP-Bed Topography of the Antarctic. 1:10,000,000 Scale Map,” British Antarctic Survey, Cam- 
bridge, 2000.

[41] R. E. Bell, M. Studinger, M. A. Fahnestock and C. A. Shuman, "Tectonically Controlled Subglacial Lakes in the Flanks of the Gamburtsev Subglacial Mountains, East Antarctica," Geophysical Research Letters, Vol. 33, No. 2, 2006, pp. 1-4.

http://dx.doi.org/10.1029/2005GL025207

[42] P. Cianfarra, A. Forieri and F. Salvini, "Modelling the Tectonic Origin of the Adventure Subglacial Trench, East
Antarctica," Geophysical Research Abstract, Vol. 11, No. 1, 2009, p. 8567

[43] M. Studinger, R. E. Bell, W. R. Buck, G. D. Karner and D. D. Blankenship, "Sub-Ice Geology Inland of the Transantarctic Mountains in Light of the New Aerogeophysical Data," Earth and Planetary Science Letters, Vol. 220, No. 3-4, 2004, pp. 391-408.

http://dx.doi.org/10.1016/S0012-821X(04)00066-4 